UKRAINIAN

ENTOMOLOGICAL JOURNAL

ISSN 2226-4272
УКРАЇНСЬКИЙ

ЕНТОМОЛОГІЧНИЙ ЖУРНАЛ

ISSN 2226-4272

UDC 595.792(477)

(C) Kaliuzhna M.O., 2020

2020, № 1-2 (18): 3-8

DOI: https://doi.org/10.15421/282001

\title{
SPECIES OF THE GENUS ADIALYTUS \\ (HYMENOPTERA, BRACONIDAE: APHIDIINAE) IN THE FAUNA OF UKRAINE
}

\author{
M.O. Kaliuzhna \\ I.I. Schmalhausen Institute of Zoology, NAS of Ukraine, Kyiv, Ukraine. \\ E-mail: kaliuzhna.maryna@gmail.com
}

Genus Adialytus is represented in Europe by four species, only two of which are recorded in the fauna of Ukraine: Adialytus ambiguus (Haliday, 1834) and Adialytus salicaphis (Fitch, 1855). Data on the distribution of these species, their trophic specialization, and habitat associations are provided on the basis of material from the collection of I. I. Schmalhausen Institute of Zoology of the National Academy of Sciences of Ukraine (SIZK) and previous publications. A. ambiguus is a broad oligophagous, however, parasitizing mostly species of the genus Sipha on Poaceae. In Ukraine, A. ambiguus is found in the Forest-Steppe zone (Kyiv, Cherkasy, Kirovohrad, Poltava regions), in the Zone of broad-leaved forests of Ukraine (Ternopil region). Adialytus salicaphis is registered for now only in the Zone of mixed forests of Ukraine (Kyiv region). This species is a narrow oligophagous and develops on aphids of the genus Chaitophorus on Salix and Populus. Its potential areal might include also Forest-Steppe zone (more probably on the Left Bank of Dnieper River) and plains of big rivers in the Steppe zone of Ukraine. The potential role of these species as biocontrol agents is discussed: A. ambiguus could be recommended for consideration as a new candidate for biocontrol of Sipha spp. and probably Rhopalosiphum spp., on cereal crops in Ukraine, while A. salicaphis is not a species of practical importance in the country now. We consider quite probable finding in Ukraine another well-distributed European species A. thelaxis (Starý, 1961), which is a parasitoid of aphids of the genus Thelaxes on oaks.

Keywords: Hymenoptera, Braconidae, aphidiines, aphid parasitoids, Adialytus, tritrophic interactions, distribution, Ukraine.

Види роду Adialytus (Hymenoptera, Braconidae: Aphidiinae) фауни України Калюжна M.O.

Рід Adialytus представлений в Європі чотирма видами. В роботі наведено дані про два види роду, зареєстровані на даний момент у фауні України: Adialytus ambiguus (Haliday, 1834) та Adialytus salicaphis (Fitch, 1855). Подано інформацію про поширення цих видів, їхн трофічну спеціалізацію та приуроченість до біотопів, обговорюється можливе практичне значення. Крім уже зареєстрованих в Україні видів роду Adialytus в майбутньому цілком можливі знахідки ще одного європейського виду, A. thelaxis (Starý, 1961), який є паразитоїдом попелиць роду Thelaxes на дубах.

Кл юч о в і сл о в а : Hymenoptera, Braconidae, афідіїни, паразитоїди попелиць, Adialytus, трофічні зв'язки, поширення, Україна.

\section{Виды рода Adialytus (Hymenoptera, Braconidae: Aphidiinae) фауны Украины}

Калюжная М.A.

Род Adialytus представлен в Европе четырьмя видами. В работе приведены данные о двух видах рода, зарегистрированных на данный момент в фауне Украины: Adialytus ambiguus (Haliday, 1834) и Adialytus salicaphis (Fitch, 1855). Дана информация о распространении этих видов, их трофической специализации и приуроченности к биотопам, обсуждается возможное практическое значение. Кроме уже зарегистрированных в Украине видов рода Adialytus в будущем вполне вероятны находки еще одного европейского вида, A. thelaxis (Starý, 1961), который является паразитоидом тлей рода Thelaxes на дубах.

К л ю че в ы е с л о в а : Hymenoptera, Braconidae, афидиины, паразитоиды тлей, Adialytus, трофические связи, распространение, Украина. 


\section{Introduction}

Genus Adialytus Förster, 1863 belongs to Aphidiinae (Hymenoptera, Braconidae), specialized koinobiont endoparasitoids of aphids (Starý, 1970; Tobias and Chiriac, 1986; Davidian, 2007; Yu et al., 2016). This is a small genus that includes seven species in the world fauna, four of which are known from Europe: widespread Adialytus ambiguus (Haliday, 1834), Adialytus salicaphis (Fitch, 1855), Adialytus thelaxis (Starý, 1961), and currently registered only in Lithuania Adialytus balticus Starý, 1979 (Stanković et al., 2015; Yu et al., 2016). Taxonomic history and diagnostic features of the genus and its species from Iran and Europe are well presented in the works of Rakhshani et al. (2012) and Stanković et al. (2015) respectively.

In Ukraine, Adialytus is represented only by two species: A. ambiguus and A. salicaphis (Kaliuzhna, 2015). Molecular analysis on the basis of COI gene barcoding showed that A. ambiguus and A. salicaphis are closely related species, and COI gene could not differentiate them well enough (Stanković et al., 2015). Despite the morphological uniformity of these species, several diagnostic characters are visible, including a difference in wing width of $A$. ambiguus and A. salicaphis (Kaliuzhna, 2014); the latter character was confirmed by geometric morphometry method (Stanković et al., 2015).

Species of the genus Adialytus are not among biocontrol agents widely used in the Euro-Mediterranean region (List..., 2020). However, there are certain expectations according to these species, mostly A. ambiguus, as well as A. salicaphis, to be among new beneficial insects in aphid biocontrol programs (Rakhshani et al., 2015; Žikić et al., 2017).

The aim of our research was to collect and organize information about species of the genus Adialytus in the fauna of Ukraine, provide information on species composition, distribution, trophic and habitat associations, and evaluate their potential role in biocontrol of economically important aphids of Ukraine.

\section{Material and methods}

Material has been collected during 2010-2019 mostly by sweeping in various regions of Ukraine, mainly on grasslands, meadows, forest edges, and openings; some specimens were reared from infested aphids. The collection of the I.I. Schmalhausen Institute of Zoology of National Academy of Sciences of Ukraine (Kyiv, Ukraine) (SIZK) was studied. Morphological characters of species were examined under Leica Z16 APO microscope equipped with a Leica DFC 450 camera and LAS V3.8 software and partly of slides under Olympus CX41 microscope with mounted camera Olympus C3040. Material is housed in SIZK. Geographical coordinates were found in Google Earth Pro, version 7.3.2.5491 (64bit), and show the location of the settlement indicated on the label. Geographical zones of Ukraine are given according to Marynych and Shyshchenko (2005).

\section{Results and discussion}

\section{Adialytus ambiguus (Haliday, 1834)}

Material: Kyiv region: (Kaliuzhna, 2019); 1 + , near Rzhyshchiv village [49 $577^{\prime} 56.76^{\prime \prime} \mathrm{N}, 31^{\circ} 2^{\prime} 35.79^{\prime \prime} \mathrm{E}$ ], grassland between field and forest, sweeping, 03.07.2010 (M. Kaliuzhna); Cherkasy region: 2 †, 5 $\hat{\text {, }}$, Chyhyryn district, Melnyky village [49 $9^{\prime} 43.29^{\prime \prime} \mathrm{N}, 32^{\circ} 19^{\prime} 0.32$ "E], steppificated meadow, 16.07.2011, sweeping (M. Kaliuzhna); Kirovohrad region: 1 9. Oleksandrivka district, near Pidlisne village [ $\left.48^{\circ} 47^{\prime} 7.97^{\prime \prime} \mathrm{N}, 32^{\circ} 15^{\prime} 11.87^{\prime \prime} \mathrm{E}\right]$, forest, meadows near forest, sweeping, 15.07.2011 (M. Kaliuzhna); Poltava region: 1 O , Kremenchuk district, Biletskivka village [48 ${ }^{\circ} 59^{\prime} 45.21^{\prime \prime N}, 33^{\circ} 20^{\prime} 56.61^{\prime \prime E}$ ], floodplain meadows, reared from Aphis fabae Scop. on Leucanthenum vulgare Lam., 10.07.2010 (O. Zubenko); 1 , , Hlobyne town, sweeping on a wheat field, 29.05.2019 (M. Kaliuzhna).

Trophic specialization: broad oligophagous.

Hosts: mostly species of genus Sipha, also there are records about parasitizing on some species of genera Aphis, Atheroides, Laingia, Rhopalosiphum (Starý, 2006; Davidian, 2007; Stanković et al., 2015), and several others genera (Yu et al., 2016), however, the latter records need a critical revision ${ }^{1}$.

1 Due to misinterpretation of A.ambiguus by various authors before the description of Lysiphlebus confusus Tremblay \& Eady, 1978 
Habitats: grasslands, fields, meadows, forest edges and openings, ruderal.

Distribution: Europe; Middle East; Central Asia; Russia [West Siberia]; China [Hubei, Sichuan], Korea, Japan; North Africa; Pakistan, India; USA (Davidian, 2007; Yu et al., 2016).

Distribution in Ukraine: Kyiv region (Kaliuzhna, 2019); Kirovohrad and Poltava regions, Cherkasy region (Kaliuzhna, 2016), Ternopil region (Kaliuzhna, 2017).

\section{Adialytus salicaphis (Fitch, 1855)}

Material: Kyiv Region: (Kaliuzhna, 2014); 1 + , Kyiv city, on Salix sp., 17.06.2015 (M. Kaliuzhna).

Trophic specialization: narrow oligophagous.

Hosts: species of genus Chaitophorus on Salix and Populus (Starý, 2006; Starý and Lukáš, 2009; Tomanović et al., 2006; Rakhshani et al., 2007, 2012, 2015).

Habitats: mixed and deciduous forests, gardens, parks, and other habitats with Salix and Populus (Starý, 2006; Starý and Lukáš, 2009).

Distribution: Europe; Middle East; Central Asia; Russia [West Syberia, Far East]; China [Henan, Shandong, Shanxi], Korea, Japan; Pakistan, India; Canada, USA, Mexico (Tobias and Chiriac, 1986; Davidian, 2007; Yu et al., 2016).

Distribution in Ukraine: Kyiv Region (Kaliuzhna, 2014).

As we can see, A. ambiguus is found mostly in the Forest-Steppe zone of Ukraine (Kyiv, Cherkasy, Kirovohrad, Poltava regions); this species is also registered in the Zone of broad-leaved forests (Ternopil region). This corresponds well with connection of A. ambiguus and its aphid hosts on grasses. As for A. salicaphis, it is registered for now only in the Zone of mixed forests of Ukraine (Kyiv region). This species is a narrow oligophagous and associated only with arboricolous aphids Chaitophorus spp. on Salix and Populus, so the collection efforts should be made in habitats that are more specific. We assume that A. salicaphis could be found most probably in habitats of "Willow-poplar forests of floodplains" that according to National habitat catalogue (Kuzemko et al., 2018) is located sporadically throughout the country, most often in the Pannonian geobotanical province (Zakarpattia region), in the Left Bank Forest-Steppe (Kyiv, Chernihiv, Sumy, Cherkasy, Poltava, and Kharkiv regions) and in southern regions of Ukraine at the floodplains of large rivers. In addition, other natural and anthropogenic habitats with willows and poplars should be checked; many of them are located in the northern and western areas of the country (Kuzemko et al., 2018).

For now, there is no record of another European species A. thelaxis, which is a parasitoid of aphids of the genus Thelaxes on oaks (Stanković et al., 2015). Nevertheless, it is registered in the countries neighboring to Ukraine: Poland, Slovakia, Hungary, Moldova, and Russia [European part] (Yu et al., 2016). We consider it quite possible that this species will be found in Ukraine in oak habitats

Table

Association of $A$. ambiguus with some economically important aphids on cereal crops in Ukraine

(Mamontova, 1987; Yu et al., 2016)

\begin{tabular}{|l|l|}
\hline \multicolumn{1}{|c|}{ Aphid } & \multicolumn{1}{c|}{ Cereal crops } \\
\hline $\begin{array}{l}\text { Sipha maydis Passerini, 1860 } \\
\text { Barley aphid }\end{array}$ & corn \\
\hline $\begin{array}{l}\text { Sipha elegans Del Guercio, 1905 } \\
\text { Bristly olive grass aphid }\end{array}$ & wheat, barley, oats \\
\hline $\begin{array}{l}\text { Rhopalosiphum maidis (Fitch, 1856) } \\
\text { Corn leaf aphid }\end{array}$ & sorghum, corn, barley, wheat, millet, rye, oats \\
\hline $\begin{array}{l}\text { Rhopalosiphum padi (Linnaeus, 1758) } \\
\text { Bird cherry-oat aphid }\end{array}$ & corn, barley, wheat, rye \\
\hline
\end{tabular}


infested by aphid T. dryophila (Schrank, 1801), which is present in the fauna of Ukraine (Mamontova, 1987; Stukalyuk, 2018).

Practical application of Adialytus spp. is not very common (Stanković et al., 2015), despite recommendations of specialists (Rakhshani et al., 2015; Žikić et al., 2017). There is a successful example of A.ambiguus application in Hawaii against the sugarcane aphid, Sipha flava (Forbes, 1885); nevertheless, the strain of the parasitoid could be of high importance. In the mentioned above example, European strain of A.ambiguus introduced to Hawaii was not established there, and only strain from Pakistan was successful in this classical biocontrol program (Culliney et al., 2003). Ecological differences between these two strains support the existence of a species complex of $A$. ambiguus (Rakhshani et al., 2012), so in case of practical application these facts should be taken into consideration. Nowadays, due to recent invasion of North American S. flava to South Europe (Hernández-Castellano and Hidalgo, 2014), the role of certain strains of its natural enemy A.ambiguus could be of high value in infested regions. In Ukraine A. ambiguus might be also a prospective candidate for control of economically important aphids on cereal crops (Table), which occupy 53,8\% of sown areas in 2020 in the country (Sown..., 2020).

As for A. salicaphis, its only known practical application in Chile against Chaitophorus leucomelas Koch, 1854 on poplars was unsuccessful; the failure probably was caused by climatic conditions (Stanković et al., 2015). It should be mentioned, more than a half of classical biocontrol programs fail due to mis-match between ecological demands of biocontrol agent and conditions of recipient environment (Moffat and Abram, 2019). Narrow trophic specialization of A. salicaphis also could matter: the efficacy of biocontrol more often tends to be higher when agents are generalists than when they are specialists (Stiling and Cornelissen, 2005).

In Ukraine such hosts of A. salicaphis as Chaitophorus leucomelas Koch, 1854, C. populeti (Panzer, 1804), C. nassonovi Mordvilko, 1894, C. vitellinae (Schrank, 1801) are mentioned as pests of willows and poplars (Mamontova, 1987). Despite raising interest in willows and poplars as energy crops in Ukraine, mostly chemical methods of pest control are used in nurseries (Sabluk et al., 2018). So, today, there is no demand for A. salicaphis application in Ukraine, nevertheless, it will remain an important member of aphidophagous guild in natural willow-poplars habitats.

\section{Conclusion}

For now, two species of genus Adialytus were found in Ukraine: A. ambiguus and A. salicaphis. The first species is broad oligophagous, found mostly in the Forest-Steppe zone of Ukraine, and also in the Zone of broad-leaved forests in Ukraine; it is connected with aphids on grasses, and could be recommended for consideration as a new potential biocontrol agent of Sipha spp. and probably Rhopalosiphum spp., on cereal crops in Ukraine. For the effective application of this species, we should consider the possible existence of $A$. ambiguus species complex in Ukraine, which could contain morphologically similar, but ecologically different members.

The second found species, A. salicaphis, is narrow oligophagous parasitoid of arboricolous Chaitophorus spp., and today it is not considered as a species of practical importance. For now A. salicaphis is registered only in the Zone of mixed forests of Ukraine; however, its potential areal is bigger and more collection efforts should be made in specific willow-poplars habitats in Left Bank Forest-Steppe, Zakarpattia region and along big rivers in the south of Ukraine, as well as in northern and western parts of the country.

We assume that one more species of the genus Adialytus, A. thelaxis, could be found in the fauna of Ukraine, because it has been already registered in adjacent countries, and its host Thelaxes dryophila is common in Ukraine. 


\section{Acknowledgments}

The author is grateful to colleagues, who helped to collect material for this study, especially to Dr. O. Zubenko (The Bohdan Khmelnytsky National University of Cherkasy) and colleagues from SIZK (Kyiv).

\section{References}

Culliney, T.W., Nagamine, W.T. and Teramoto, K.K., 2003. Introductions for biological control in Hawaii 1997-2001. Proceedings of the Hawaiian Entomological Society, 36: 145-153.

Davidian, E.M., 2007. Fam. Aphidiidae. In: A. S. Leley, ed. Keys to the insects of Russian Far East. Vladivostok: Dal'nauka, IV (5): 192-254. (in Russian: Давидьян, E.M. Сем. Aphidiidae).

Hernández-Castellano, C. and Hidalgo N. P., 2014. First record of the yellow sugarcane aphid Sipha flava (Forbes) (Hemiptera Aphididae) in the European continent. Redia-Giornale Di Zoologia, 97: 137-140.

Kaliuzhna, M.O., 2014. First records and comparative notes of twelve aphidiid species (Hymenoptera, Aphidiidae) from the fauna of Ukraine. Vestnik Zoologii, 48 (5): 387-400. doi: 10.2478/vzoo-2014-0047.

Kaliuzhna, M.O., 2015. Aphidiid wasps (Hymenoptera, Aphidiidae) of the forest-steppe zone of Ukraine. PhD Thesis. Schmalhausen Institute of Zoology (in Ukrainian: Калюжна, M.О. Їздці-афідіїди (Нуmеnoptera, Aphidiidae) лісостепової зони України).

Kaliuzhna, M.O., 2016. First Data on Aphidiine Wasps (Braconidae: Aphidiinae) of The Kaniv Nature Reserve. Ukrainian Entomological Journal, 1-2 (11): 29-32.

Kaliuzhna, M.O., 2017. Species composition and host-parasitoid interactions of aphidiine wasps (Hymenoptera, Braconidae, Aphidiinae) of the National Nature Park "Dniester Canyon”. Ukrainian Entomological Journal, 2 (13): 29-36 (in Ukrainian: Калюжна, М.О. Видовий склад та хазяїно-паразитні зв'язки їздців-афідіїн (Hymenoptera, Braconidae, Aphidiinae) національного природного парку «Дністровський каньйон»).

Kaliuzhna, M.O., 2019. Aphid parasitoids (Hymenoptera, Braconidae, Aphidiinae) of the Forest zones of Ukraine: species composition and habitat associations. Ukrainian Entomological Journal, 2 (17): 25-35. https://doi.org/10.15421/281910

Kuzemko, A.A., Didukh, Ya.P., Onishchenko, V.A., and Sheffer, Ya. eds., 2018. National habitat catalogue of Ukraine. Kyiv: FOP Klymenko Yu.Ya. (in Ukrainian: Куземко, А.А., Дідух, Я.П., Онищенко, В.А., та Шефбер, Я. ред. Національний каталог біотопів Украӥни).

List of biological control agents widely used in the EPPO region. EPPO Standards on Safe use of Biological Control PM6/3.[online] Availableat:<https://www.eppo.int/media/uploaded_images/RESOURCES/eppo_standards/pm6/ pm6-03-2020-en.pdf> [Accessed 10 October 2020].

Mamontova, V.A., 1987. True aphids - Aphidoidea. In: V. G. Dolin, ed. 1987. Vrediteli sel'skokhozyajstvennykh kul'tur i lesnykh nasadzhenij. Vol. 1. Vrednye nematody, mollyuski, chlenistonogie. Kiev: Urozhay (in Russian : Мамонтова, B.A. Настоящие тли - Aphidoidea).

Marynych, O.M. and Shyshchenko P.H., 2005. Physical Geography of Ukraine. Kyiv: Znannia (in Ukrainian: Mapuruu, О.M. і Шищенко, П.Г. Фізична географія України).

Moffat, C.E. and Abram, P.K., 2019. Rethinking biological control programs as planned invasions. 6th International entomophagous insects conference (Perugia, Italy, 9-13 September 2019). Abstract book: 94. Perugia.

Rakhshani, E., Starý, P., Tomanović, Ž. and Mifsud, D., 2015. Aphidiinae (Hymenoptera, Braconidae) aphid parasitoids of Malta: review and key to species. Bulletin of the Entomological Society of Malta, 7: 121-137. doi: 10.17387/bullentsocmalta.2015.10.

Rakhshani, E., Starý, P. and Tomanović, Ž., 2012. Species of Adialytus Förster, 1862 (Hymenoptera, Braconidae, Aphidiinae) in Iran: taxonomic notes and tritrophic associations. ZooKeys, 221: 81-95. doi: 10.3897/zookeys.221.3541

Rakhshani, E., Talebi, A.A., Starý, P., Tomanović, Ž. and Manzari, S., 2007. Aphid-parasitoid (Hymenoptera, Braconidae, Aphidiinae) associations on willows and poplars in Iran. Acta Zoologica Academiae Scientiarum Hungaricae, 53 (3): 281-292.

Sabluk, V.T., Sinchenko, V.M., Hryshchenko, O.M., Smirnykh, V.M., Pedos, V.P. and Suslyk, L.O., 2018. Pests of energy willow and practices to control their number. Naukovi pratsi Instytutu bioenergetychnyh kul'tur i tsukrovyh buriakiv, 26: 41-48. (in Ukrainian: Саблук, В.Т., Сінченко, В.М., Грищенко, О.М., Смірних, В.М., Педос В.П. та Суслик, Л.О. Шкідники верби енергетичної та заходи контролю їхньої чисельності).

Sown areas of agricultural crops by their types in 2020. [online] State Statistics Service of Ukraine. Available at: <http:// www.ukrstat.gov.ua/operativ/operativ2020/sg/ppsgk/ppsgk2020.xlsx> [Accessed 15 October 2020] (in Ukrainian: Посівні площі сільськогосподарських культур за їх видами у 2020 році).

Stanković, S.S., Petrović, A., Ilić Milošević, M., Starý, P., Kavallieratos, N.G., Žikić, V., and Tomanović, Ž., 2015. Morphological and molecular characterization of common European species of Adialytus (Hymenoptera: Braconidae: Aphidiinae) based on the mtCOI barcoding gene and geometric morphometrics of forewings. European journal of entomology, 112(1): 165-174. doi: 10.14411/eje.2015.007.

Starý, P., 2006. Aphid parasitoids of the Czech Republic (Hymenoptera: Braconidae, Aphidiinae). Praha: Academia.

Starý, P. and Lukáš J., 2009. Aphid parasitoids and their tritrophic associations in Slovakia (Hymenoptera: Braconidae, Aphidiinae). Acta Hymenopterologica Slovaca. 1: 1-63. 
Starý, P., 1970. Biology of aphid parasites (Hymenoptera: Aphidiidae) with respect to integrated control. The Hague: W Junk (Series entomologica, vol. 6).

Stiling, P. and Cornelissen, T., 2005. What makes a successful biocontrol agent? A meta-analysis of biological control agent performance. Biological Control, 34(3): 236-246. https://doi.org/10.1016/j.biocontrol.2005.02.017

Stukalyuk, S. V., 2018. Supercolony of Dolichoderus quadripunctatus Linnaeus (Hymenoptera, Formicidae). Biology Bulletin Reviews, 8: 449-462.

Tobias, V.I. and Chiriac, I.G., 1986. Fam. Aphidiidae. In: G. S. Medvedev, ed. Keys to the insects of the European part of the USSR. Lenindrad: Nauka, 3(5): 232-308. (in Russian: Тобиас, В.И. и Кирияк, И.Г. Сем. Aphidiidae).

Tomanović, Ž., Kavallieratos, N.G., Starý, P., Petrović-Obradović, O., Tomanović S. and Jovanović S., 2006. Aphids and parasitoids on willows and poplars in southeastern Europe (Homoptera: Aphidoidea; Hymenoptera: Braconidae, Aphidiinae). Journal of Plant Diseases and Protection, 113: 174-180. https://doi.org/10.1007/BF03356176

Yu, D.S., van Achterberg, C., and Horstmann, K., 2016. World Ichneumonoidea 2015: Taxonomy, Biology, Morphology and Distribution. CD/DVD. Taxapad, Vancouver, Canada.

Žikić, V., Lazarević, M. and Milošević, D., 2017. Host range patterning of parasitoid wasps Aphidiinae (Hymenoptera: Braconidae). Zoologischer Anzeiger, 268: 75-83. https://doi.org/10.1016/j.jcz.2016.10.001.

\section{ORCID}

Kaliuzhna M.O.: https://orcid.org/0000-0002-9265-0195

Отримано 20.11.2020

Received 20.11.2020

Підиисано до друку 18.12.2020

Accepted 18.12.2020 